płk rez. prof. dr hab. inż. Zbigniew Ścibiorek ${ }^{1}$

Przyjęty/Accepted/Принята: 07.07.2014;

Zrecenzowany/Reviewed/Рецензирована: 25.05.2015;

Opublikowany/Published/Опубликована: 30.09.2015;

\title{
Zarządzanie kryzysowe a teoria organizacji i zarządzania
}

\author{
Crisis Management - Contrast with Organization and Management Theory
}

\author{
Антикризисное управление и теория организации и управления
}

\begin{abstract}
A BSTRAKT
Cel: Wykazać uwarunkowania i znaczenie zarządzania podczas zaistnienia zdarzeń niekorzystnych dla ludzi i (lub) środowiska. Wprowadzenie: Zarządzanie kryzysowe odbywa się w nader złożonych warunkach. Jest uwarunkowane szeregiem czynników. One to w różny sposób wpływają na podejmowane działania i ich efektywność. Praktyka jednoznacznie ukazuje, że wiele zależy od tego jaka jest procedura oddziaływania na ludzi, zwłaszcza ratowników. Nie mniejsze znaczenie ma sposób wykorzystania posiadanego sprzętu i innych rzeczy. W zarządzaniu kryzysowym można wykorzystywać osiągnięcia teorii organizacji i zarządzania. Taki jest cel artykułu. Nie można jednak zapominać o tym, że akcje ratownicze prowadzone są przez organizacje publiczne, najczęściej zhierarchizowane, jak np. Państwowa Straż Pożarna. Fakt ten w pewien sposób ogranicza możliwości stosowania rozwiązań „cywilnych”, ale ich nie wyklucza. Wiele zależeć będzie od warunków zaistniałej sytuacji i od tego jaka jest skala potencjalnego zagrożenia dla ludzi i środowiska. Chociażby dlatego bardzo istotne jest szybkie rozpoznanie (zdiagnozowanie) zdarzenia, aby stosownie do tego zaangażować niezbędne siły i środki oraz dążyć do ich efektywnego wykorzystania. Niebagatelny wpływ na proces zarządzania kryzysowego ma fakt, że w porównaniu z minionymi laty, obecnie postęp cywilizacyjny powoduje, że coraz szybciej powstają (pojawiają się) nowe czynniki, zmienia się zakres ich znaczenia. Taki wniosek wysnuto po przeprowadzonych analizach możliwych zdarzeń niekorzystnych dla otaczającej nas rzeczywistości. Zmianie ulegają również wzajemne zależności między poszczególnymi czynnikami. W takiej sytuacji nader trudne staje się precyzyjne przedstawienie w jaki sposób rozwiązywać pojawiające się problemy. Można i trzeba sięgać do zdobyczy nauki i to niezależnie od tego przez kogo i gdzie zostały wygenerowane rozwiązania. Twórczo trzeba rezygnować z tego co kiedyś przynosiło sukcesy. Współcześnie skala zjawisk jest całkiem inna. Nieodzowne jest analizowanie zjawisk kategoriami strategicznymi, niejednokrotnie w wymiarze międzynarodowym.

Wnioski:

1) Podczas zarządzania kryzysowego można wykorzystywać wiedzę z zakresu teorii organizacji i zarządzania.

2) Nie ma i nie zostanie wygenerowane rozwiązanie uniwersalne do zastosowania podczas zdarzeń niekorzystnych dla ludzi i (lub) środowiska.

3) W procesie zarządzania kryzysowego wiele zależeć będzie od inwencji ludzi kierujących akcją ratowniczą i biorących w niej udział.
\end{abstract}

Słowa kluczowe: zarządzanie, zarządzanie kryzysowe, uwarunkowania, proces, ludzie

Typ artykułu: artykuł przeglądowy

\section{A BSTRACT}

Aim: Demonstrate the conditions and importance of managing incidents, which have an adverse impact on the environment and people. Introduction: Crisis management is conducted in very complex conditions. It is conditioned by a range of factors, which in a variety of ways influence the measures taken and their ultimate outcomes. Practice reveals that much depends on procedures, which impact on people, especially personnel engaged with rescue operations. Equally important is the way in which equipment and other resources are utilised. Crisis management can exploit the achievements in organization and management theory. It should be borne in mind that rescue operations are conducted by public organizations, usually with a hierarchical structure, such as the National Fire Service. To some extent this limits the application of "civil" solutions, but it does not rule them out. Much will depend on the situation and on the scale of potential risks to humans and the environment. Therefore, it is very important to quickly recognise (diagnose) incidents so that appropriate resources can be selected and utilised in the most effective way. Compared with the past, progressive development of civilisation is accompanied by quickly emerging influences where the span of meaning changes, with a consequential impact on the process of crisis management. Interrelationships between influences are also changing and in such circumstances it becomes extremely difficult to

1 Wyższa Szkoła Oficerska Wojsk Lądowych we Wrocławiu / Land Forces Military Academy, Poland; zbscibi@wp.pl; 
show precisely how emerging problems can be addressed. However, achievements in science provide a wealth of information, which can and should be harnessed, regardless of where and by whom such information was generated. By contrast, the current scale of incidents is quite different, compared with the past. Consequently, there is a need to creatively abandon traditional approaches and importantly, analyse incidents in a strategic context, frequently within an international dimension.

\section{Conclusions:}

1) It is possible to utilise elements of organisation and management theory during crisis management situations.

2) There is no universal solution, which can be applied to all incidents, which adversely impact on society and the environment.

3) During crisis management situations much will depend on the creativity of commanders and people participating in rescue operations.

Keywords: management, crisis management, conditions, process, people Type of article: review article

\section{АННОТАЦИЯ}

Цель: Продемонстрировать важность и значение управления во время возникновения неблагоприятных событий для людей и (или) окружающей среды.

Введение: Антикризисное управление осуществляется в очень сложных условиях. Оно зависит от ряда факторов, которые влияют на применяемые действия и их эффективность разным образом. Практика показывает, что многое зависит от вида процедуры воздействия на людей, особенно на спасателей. Не менее важен способ использования имеющегося оборудования и других вещей. В антикризисном управлении можно использовать достижения теории организации и управления. Такова цель этой статьи. Нельзя, однако, забывать о том, что спасательные работы проводятся государственными органами, чаще всего иерархической структуры, такими как, например, Государственная Пожарная Служба Польши. Этот факт в какой-то степени ограничивает возможности использования „гражданских” решений, но их не исключает. Многое будет зависеть от условий данной ситуации и размера потенциальной угрозы для людей и среды. Хотя бы, поэтому очень важно быстро распознать событие, чтобы соответственным и эффективным образом распределять и использовать доступные силы и средства. Немалое влияние на процесс антикризисного управления имеет тот факт, что в сравнении с прошлыми годами, в настоящее время прогресс цивилизации проводит к тому, что всё чаще появляются новые факторы и изменяется уровень их важности. Такой вывод сделан после проведения анализов возможных негативных для окружающей нас среды событий. Изменениям подвергаются также взаимные зависимости между отдельными факторами. В такой ситуации очень сложно точно описать, как решать появляющиеся проблемы. Можно и нужно использовать достижения науки независимо от того кем и где были разработаны решения. Нужно уметь творчески отклоняться от того, что раньше принесло успехи. Сегодня масштабы событий весьма отличаются. Неотъемлемым является стратегический анализ явлений неоднократно на международном уровне. Выводы:

1) Во время антикризисного управления можно использовать знания в области теории организации и управления.

2) Нет и не будет универсального решения для применения во время негативных для людей и (или) среды явлений.

3) В процессе антикризисного управления многое будет зависеть от креативности людей, руководящих спасательной работой и участвующих в ней.

Ключевые слова: управление, антикризисное управление, обусловленность, процесс, люди

Вид статьи: обзорная статья

\section{Wstęp}

Tytuł artykułu budzi określone skojarzenia. Mogą one wynikać z kilku powodów. Zdaniem autora najistotniejszy dotyczy tego, że w obu członach tytułu występuje ten sam wyraz. To on stał się głównym powodem do analizy rozumienia (pojmowania) tego samego, ale w odniesieniu do różnych kwestii - bardzo ogólnych i odnoszących się do konkretnego zdarzenia, jakim jest zarządzanie kryzysowe. Ponadto w jednym i drugim przypadku mamy do czynienia $z$ tym co obydwa zarządzania łączy. Elementem tym jest fakt, że wyróżniamy cztery fazy i tyle samo etapów, jeśli chodzi o zarządzanie kryzysowe. W teorii zarządzania wyróżniamy cztery funkcje, którymi są: planowanie, organizowanie, motywowanie (lub przewodzenie) i kontrolowanie. Z kolei proces zarządzania kryzysowego dzielimy na cztery fazy: zapobiegania, przygotowania, reagowania i odbudowy. Przy czym trzeba zaznaczyć, że wyżej wymienione fazy wyrażają się zapobieganiem możliwym sytuacjom kryzysowym i przygotowaniem do nich, reagowaniem (rozwiązywaniem) w wypadku ich wystąpienia oraz odbudową jako powrotem do stanu normalnego funkcjonowania. Sytuacje te powodują utratę kontroli nad wydarzeniami z nimi związanymi i możliwość zaistnienia jakościowej zmiany systemowej, a to wymaga podjęcia zdecydowanych, wszechstronnych kroków zaradczych [1]. Bez ryzyka popełnienia błędu można więc stwierdzić, że na potrzeby teorii zarządzania kryzysowego, kryzysem będziemy nazywali kulminacyjną fazę eskalacji zagrożenia, często całkowitą utratę kontroli nad zaistniałą sytuacją, w której następuje przełom (punkt zwrotny) jakiegoś procesu, w wyniku którego dany podmiot może ulec likwidacji, destrukcji lub zostać pozbawiony szans powrotu do normalności, a nawet rozwoju [2]. Zatem kryzys to załamanie dotychczasowego stanu rzeczy czy też porządku wewnętrznego skutkujący trudnymi do jednoznacznego określenia konsekwencjami.

Po tych wyjaśnieniach terminologicznych, czy też formalnych, można zastanowić się nad kwestią dotyczącą podmiotu zarządzania. Z uwagi na charakter czasopisma autor nie odniesie się do kwestii zarządzania „normalnego”, czy też jak niektórzy określają „cywilnego” szeroko 
opisanego w szeregu różnego rodzaju pozycji zwartych, a skupi uwagę na specyfice zarządzania kryzysowego. Refleksje będą dotyczyły ludzi (personelu), ponieważ zdaniem autora słuszna jest teza, że ludzie to najistotniejszy kapitał każdej organizacji [3], [4]. W całej rozciągłości odnosi się to do organizacji (instytucji) publicznych, które podczas zaistnienia sytuacji kryzysowej są w tak zwanej pierwszej linii.

\section{Analiza sytuacji kryzysowej}

Druga dekada XXI wieku jest różnie oceniana. Niebagatelny wpływ na optykę postrzegania wielu zjawisk ma stabilizacja sytuacji w Europie Środkowej. Jednakże współcześnie, w dobie znacznego wzrostu bezpieczeństwa międzynarodowego, poszczególne państwa i regiony stają przed nowymi wyzwaniami, których nie można jednoznacznie zdefiniować. Pojawia się szereg zagrożeń, których skutki trudno sobie wyobrazić. Zagrożenia te wynikają z różnych sytuacji, jakie mogą zaistnieć w skali mikro i makro. Mogą one mieć różny charakter i zasięg. Implikować to będzie skalą zaangażowanych sił i środków. Zawsze jednak do likwidacji skutków zdarzeń kryzysowych zaangażowani zostaną ludzie, którym przyjdzie działać w warunkach ekstremalnych. Wiele zależało będzie przede wszystkim od postawy ratowników. Istotny wpływ na skalę możliwych zniszczeń, zasięg i stopień oddziaływania na społeczeństwa mieć będą postawy i zachowania poszczególnych osób, jak i społeczności lokalnych [5].

Możliwość zaistnienia zdarzeń kryzysowych, niekiedy noszących znamiona katastrofy, oraz skutki tych niekorzystnych zdarzeń dla społeczeństwa i środowiska implikują potrzebę perfekcyjnego wykorzystania wszystkiego co znajduje się w gestii władz samorządowych, aby zminimalizować konsekwencje ewentualnych wypadków niebezpiecznych. Bardzo istotne będzie właściwe kierowanie ludźmi, którzy będą zaangażowani w likwidację skutków takich zdarzeń, nad wyraz niekorzystnych dla społeczności lokalnych. Dużą rolę odegra profesjonalizm osób dowodzących akcją, którzy obok tradycyjnego zarządzania jednostką samorządową lub administracyjną, będą musieli kierować akcją likwidacji skutków sytuacji kryzysowych. To od ludzi, ich postaw, zaangażowania, odporności zależy m.in. umiejętność wykorzystania posiadanych sił i środków. Istotną rolę odgrywać będą instytucje publiczne, które posiadają profesjonalnie przygotowany personel i dysponują specjalistycznym sprzętem. Duże znaczenie będą miały obieg informacji oraz czas.

Warunki funkcjonowania wszelkich organizacji na początku drugiej dekady XXI wieku są nader złożone. To co obserwujemy jest rezultatem przeobrażeń, które dotyczą wszystkich sfer życia publicznego i są pochodną szeregu zdarzeń. Od najdawniejszych czasów działalność kulturalna, gospodarcza, mniej lub bardziej swobodnie, przekraczała granice polityczne, kulturalne, czy też etniczne. Powstawały sieci powiązań i interesów ekonomicznych, tworzyły się i upadały regionalne, a nawet niemal światowe ośrodki dominacji i (lub) handlu określonymi grupami towarów. Współcześnie organizacje poprzez uczestnictwo w procesie globalizacji tworzą gospodarkę światową, która umożliwia swobodny przepływ dóbr, usług, czy też czynników wytwórczych. Jednoczesny rozwój technologii powoduje lepsze i dokładniejsze poznanie świata, dostarczając coraz więcej informacji o nim, przez co wydaje się on coraz mniejszy. Świat staje się wspólnym rynkiem, na którym ludzie bez względu na to gdzie mieszkają, pragną życia w warunkach spokoju i poczucia bezpieczeństwa wewnętrznego. Jednakże ten stan staje się coraz bardziej zagrożony, co zmusza społeczeństwo do dynamizowania działań ukierunkowanych na doskonalenie systemu zarządzania kryzysowego.

W tej chwili, w dobie gospodarki rynkowej, globalne przedsiębiorstwa muszą pominąć różnice między krajami oraz kulturami i zamiast tego skoncentrować się na zaspokojeniu uniwersalnych potrzeb konsumentów, spośród których ukierunkowane na bezpieczeństwo nabierają znaczenia pierwszoplanowego. Jednocześnie poszczególne organizacje publiczne - chociażby z uwagi na charakter działalności, który prowadzą, zasięg i skalę działania, różne cele, zadania, kłopoty, trudności itp. - stają się coraz bardziej specjalistyczne. Niemniej jednak w coraz większym stopniu sygnalizują, że są elementem systemu regionalnego (lokalnego) i narodowego. Akcentują swój prospołeczny charakter, zgodnie z którym człowiek i jego bezpieczeństwo zajmują miejsce centralne. Przy czym, co godne jest podkreślenia, coraz większą uwagę przywiązuje się do kwestii związanych z etyką w prowadzonej działalności. W ślad za tym poczynania prospołeczne i proekologiczne absorbują przedsiębiorców w dość istotny sposób.

\section{Nowe okoliczności}

Przeobrażający się świat niesie za sobą nowe wymagania. Rodzą się coraz większe oczekiwania w stosunku do dyscyplin naukowych, jakimi są nauki o bezpieczeństwie i nauki o obronności [6]. Wielość ujęć oraz ciągła ewolucja poglądów na temat bezpieczeństwa narodowego powoduje, że kwestie te nie zawsze są należycie interpretowane. Wśród szerokich kręgów społeczeństwa dominują najczęściej tzw. potoczne teorie bezpieczeństwa. Istotną zaś cechą wiedzy potocznej są złudzenia, czyli różnego rodzaju błędy i deformacje poznawcze, na ogół nieuświadamiane i dlatego tak trudne do zakwestionowania. Pozwalają one człowiekowi, co prawda, na zachowanie pewności i orientacji w świecie, wynikających ze złudnego zrozumienia przez niego otaczającej rzeczywistości, lecz oddalają go od poznawania prawdy. $Z$ tego faktu wynika, iż potocznej wiedzy o bezpieczeństwie nie należy lekceważyć. Trzeba ją ujawniać i rzetelnie precyzować w aspekcie teoretycznym. Mówiąc językiem postmodernistów, należy zainicjować proces rekonstrukcji i dekonstrukcji wcześniej wymienionych dyscyplin naukowych. Wyzwania, przed jakimi stanęła ludzkość, wymuszają bowiem konieczność działania na wielu płaszczyznach, według określonej uznanej teorii. Zarówno uczeni, jak i politycy zajmujący się problematyką bezpieczeństwa są zgodni, że zakres pojęciowy permanentnie rozszerza się wskutek rozwoju cywilizacyjnego o nieznane dotychczas wyzwania i zagrożenia oraz nowe środki i sposoby ich eliminowania. Nie można pomijać implikacji wynikających z faktu, że współczesna treść pojęcia bezpieczeństwa państwa obejmuje zarówno kwestie 
polityczne i militarne, jak i aspekty gospodarcze, ekologiczne, społeczne i etniczne[7].

Diagnozując otaczającą nas rzeczywistość, mamy podstawy stwierdzić, że obok zjawisk korzystnych dla ludzkości pojawiają się zagrożenia, o których niejednokrotnie myślano, że przeszły już do historii. Koresponduje to z tym, że dla większości państw, uczestników życia międzynarodowego, troska o zapewnienie własnego bezpieczeństwa jest potrzebą o charakterze egzystencjalnym. Bez jej zaspokojenia nie jest możliwe realizowanie wszystkich innych celów i aspiracji zarówno państw, narodów, sojuszy, jak i społeczeństw [8].

Procesy umiędzynarodawiania coraz wyraźniej dotykają także sfery społecznej i samego człowieka, kreując nową jakość życia. Zmieniają jego zachowania, postawy i systemy wartości. Człowiek poddawany jest działaniu takich procesów jak: przenikanie kultur, wzrost wzajemnych powiązań, naśladownictwo itp. [9]. Ich skutkiem jest osłabienie tożsamości narodowej i kulturowej, homogenizacja postaw, zwyczajów i tradycji, co prowadzić może do uniwersalizacji społecznych norm i wartości, do ukształtowania obywatela świata, oderwanego od korzeni narodowych i terytorium. We współczesnym świecie dostrzec należy także inną tendencję - działanie swoistej siły odśrodkowej, będącej próbą obrony i ochrony narodowych wartości. Może właśnie ta siła sprawi, że koncepcja uniwersalnego człowieka nie jest jedyną możliwą wizją dla przyszłych pokoleń. Wiele osób wyraża przekonanie, że niezależnie od dokonanych przeobrażeń człowiek nadal pozostanie sobą, będzie mieć swój niepowtarzalny system wartości, swoją ocenę zjawisk i poczucie przynależności do społeczności, niekiedy indywidualną ocenę szeregu zjawisk społecznych, co być może wypacza pewne kwestie $\mathrm{z}$ obszaru bezpieczeństwa wewnętrznego.

Podobnie jest w odniesieniu do instytucji publicznych predysponowanych do udziału (realizacji zadań) w sytuacjach kryzysowych. Personel tych organizacji musi posiadać szczególne predyspozycje, a kwestie ludzkie postrzegać jako bardzo istotne - wprost pierwszoplanowe. Fakt ten przemawia za tym, że dobór, zwłaszcza ratowników, musi być bardzo staranny. Inaczej być nie może. Każdy człowiek w zdarzeniach (sytuacjach) kryzysowych niesie pomoc drugiej osobie i środowisku w którym żyjemy. Niejednokrotnie czyni to z narażeniem zdrowia lub życia.

Przybliżone powyżej kwestie mogą być podstawą do sformułowania szeregu wniosków. Część wspomnianych refleksji odnosi się do warunków w jakich działają współczesne organizacje publiczne, np. Państwowa Straż Pożarna, Policja. Najogólniej rzecz ujmując, nie są one zbyt łaskawe. Wobec personelu, przełożonych, czy też kadry zarządzającej, poprzeczka wymagań i oczekiwań, ukierunkowana przede wszystkim na dużą efektywność działania, jest podniesiona dość wysoko. Zapewne w przyszłości sytuacja ulegnie zmianie w kierunku jeszcze większej profesjonalizacji, na co niewątpliwy wpływ będą miały zmienność warunków i dynamika zachodzących przeobrażeń, a także wzrastająca możliwość zaistnienia zdarzeń niekorzystnych. Zdarzały się one w przeszłości i zapewne będą występowały, pomimo coraz doskonalszych rozwiązań monitorowania i zapobiegania różnego rodzaju zagrożeniom, które w wielu przypadkach trudno jednoznacznie zdefiniować.

Dziś zmienność warunków życia ludzi, funkcjonowania wszelkich firm i instytucji jest czymś naturalnym. Zbiór uwarunkowań występujących zarówno w przypadku konkretnego podmiotu, jak i jego otoczenia jest stosunkowo prosty do zdefiniowania. Całkiem inaczej przedstawia się sprawa, jeśli chodzi o określenie wzajemnych powiązań poszczególnych czynników i ich wpływu na konkretne zjawiska występujące w otaczającej nas rzeczywistości. Teoretycy, przy wsparciu praktyków, niejednokrotnie podejmują próby uporządkowania tych czynników, określenia który z nich, w jaki sposób i z jaką mocą oddziałuje na społeczeństwo i środowisko. W wielu wypadkach próby te kończą się sukcesem, zwłaszcza wtedy, gdy mamy do czynienia $\mathrm{z}$ konkretnym podmiotem (zbiorem), funkcjonującym w dającej się zdefiniować rzeczywistości. Jednak w sytuacji próby uogólnienia sprawa przedstawia się całkiem inaczej. Na taki stan rzeczy składa się wiele czynników. Niebagatelny wpływ na to ma fakt, że $\mathrm{w}$ porównaniu $\mathrm{z}$ minionymi laty, obecnie postęp cywilizacyjny powoduje, że coraz szybciej powstają (pojawiają się) nowe czynniki, zmienia się zakres ich znaczenia. Zmianie ulegają również wzajemne zależności między poszczególnymi czynnikami [10]. W takiej sytuacji nader trudne staje się precyzyjne przedstawienie warunków funkcjonowania współczesnych organizacji publicznych, o czym wspomina się w szeregu opracowaniach [11]. Pocieszające jest to, że ten stan coraz częściej zaczyna przybierać charakter zjawisk uporządkowanych. To z kolei stwarza warunki do powstawania korzystnych procesów, jak chociażby związanych ze zwiększaniem możliwości rozpoznawania i neutralizowania niekorzystnych zjawisk, które w ocenie społecznej mogą podwyższać poziom bezpieczeństwa wewnętrznego.

Dodającym otuchy jest fakt, że coraz większe grono osób widzi, że wraz z dynamiką zmian, przyjmowane rozwiązania, sposób realizacji zadań stosunkowo szybko się dezaktualizują. Stosownie więc do przeobrażeń dokonywane są modyfikacje rozwiązań, które gwarantowały wysoki poziom satysfakcji w minionych latach. Przy czym zmiany te stały się coraz bardziej nowatorskie, kosztowne, szybkie i trudne do przewidzenia. Nie pozostaje to bez wpływu na kierowanie (zarządzanie czy dowodzenie) w sytuacjach (zdarzeniach) kryzysowych, które staje się coraz trudniejszą sztuką, a na poprawność dokonywanych rozstrzygnięć wpływa wiele czynników. Podejmowane decyzje, odnoszące się do przyszłości, obarczone są odczuciem dużej niepewności. Przewidywanie i planowanie (prognozowanie) staje się bardziej złożone, zawiera coraz więcej znaków zapytania. Coraz częściej zachodzi konieczność kompleksowego analizowania otoczenia i uregulowań międzynarodowych, zwłaszcza unijnych, i dostrzegania większej niepewności co do tendencji rozwojowych analizowanych zjawisk. Zbieżne jest to $\mathrm{z}$ tezą, że złożoność i niepewność otoczenia wzrastają w miarę umiędzynarodowienia różnorodnych stosunków między poszczególnymi regionami, narodami, organizacjami (stowarzyszeniami), a nawet społecznościami lokalnymi. 


\section{Implikacje uwarunkowań na proces zarządzania kryzysowego}

Zakreślone warunki akcentują potrzebę myślenia strategicznego [12]. Ono odgrywa pierwszoplanową rolę i stanowi istotne antidotum na złożoność współczesności. Strategiczne podejście do wielu zjawisk to szczególnego rodzaju paradygmat działania osób na stanowiskach kierowniczych (dowódczych). Takie pojmowanie spraw jest nieodzowne chociażby dlatego, że każde działanie, zwłaszcza nierutynowe, o złożonej strukturze wymaga namysłu i refleksji, zidentyfikowania i przeanalizowania (rozważenia) możliwych skutków, naturalnie według wiedzy i intuicji osoby, która je podejmuje. Wymaga ono więc myślenia, czyli dążenia do poznania, rozumienia i wnioskowania, skupienia uwagi na tym, co wymaga rozwiązania problemu i zastanowienia się, co zrobić i jak to uczynić oraz jakie będą tego skutki. W całej rozciągłości odnosi się to również do sytuacji kryzysowych.

Wnikliwa analiza szeregu dokumentów oraz zapisów w publikacjach zwartych pozwala wysnuć wniosek, że proces zarządzania kryzysowego można różnie definiować. W ślad za tym wymienia się szereg elementów tych zdarzeń, które nie są zdarzeniami korzystnymi dla pojedynczych osób, społeczności i szeroko rozumianej infrastruktury, a nawet pewnych elementów związanych z funkcjonowaniem jednostek samorządu terytorialnego. Na użytek niniejszego artykułu i po dokonaniu znaczącego uogólnienia postawiono tezę, że w sytuacjach kryzysowych zawsze uczestniczą ludzie. Ich rola może być i jest zróżnicowana. Mogą to być ratownicy, jak i osoby, które są w potrzebie w wyniku zaistnienia zdarzeń dla nich niekorzystnych. Innymi słowy ludzie mogą znajdować się po przeciwległych stronach, ale nie można ich postrzegać jako osób prezentujących odmienne stanowiska w kwestii bezpieczeństwa.

Teraźniejsze lata dowodzą, że prawdopodobieństwo wystąpienia sytuacji kryzysowej jest stosunkowo duże. Takie postrzeganie rzeczywistości to przede wszystkim wynik oceny przeobrażeń jakie się dokonują wokół nas, o czym zasygnalizowano na wstępie. Wszystko się zmienia, a skala i tempo przeobrażeń jest coraz intensywniejsze i przybiera większe rozmiary. Do rozwiązywania wszelkich problemów, podejmowania decyzji, nieodzowna jest informacja. Jest jej dużo, co wcale nie sprzyja rzetelnej ocenie analizowanych zjawisk. Nadmiar informacji sprawia, że jej selekcja staje się przedsięwzięciem złożonym i wymagającym czasu. Obecnie przysłowiowe oddzielenie ziarna od plew absorbuje w stopniu dość istotnym. A przecież bez wiarygodnej informacji trudno jest planować i podejmować racjonalne działania $\mathrm{z}$ udziałem ludzi w rolach atutowych.

Informacja pośrednio lub bezpośrednio związana jest $\mathrm{z}$ czasem. On też ma swoje wymagania. W kontekście potencjalnych zagrożeń i ewentualnych ich skutków akcentuje szybkość działania. Współcześnie analiza uwarunkowań zaistnienia sytuacji kryzysowej rozumianej jako zespół okoliczności zewnętrznych i wewnętrznych, wpływających na dany układ w taki sposób, iż zaczynają się i trwają w nim zmiany, odbywa się w uwarunkowaniach dynamicznych. Nietrafna diagnoza czy też opóźnienie może skutkować następstwami trudnymi do jednoznacznego zdefiniowania, a ich rezultatem tych zmian może być jakościowo nowy układ lub nowa struktura i funkcja w układzie istniejącym.

$\mathrm{W}$ wielu przypadkach postęp cywilizacyjny $\mathrm{z}$ wszelkimi jego implikacjami nie jest łaskawy dla ludzi i środowiska. Aby się o tym przekonać, nie potrzeba zbytniego wysiłku. Codziennie słyszymy o wydarzeniach, które nie chcielibyśmy, aby dotyczyły nas czy też bliższego i (lub) dalszego otoczenia naszego miejsca pracy, czy przebywania. Katastrofy naturalne czy awarie techniczne już dawno przestały być zdarzeniami sporadycznymi. Współcześnie sytuacje kryzysowe występują dość często i mogą spowodować zagrożenia:

- zwyczajne w następstwie niekontrolowanej, codziennej działalności społeczno-gospodarczej,

- nadzwyczajne w wyniku awarii, katastrofy i klęski żywiołowej.

Wymienione zagrożenia nie są korzystne dla ludzi i środowiska. Przy rozpatrywaniu różnorodnych kwestii dotyczących potencjalnych niebezpieczeństw zasadne jest podkreślić jeszcze jeden aspekt rozpatrywanej problematyki. Przy istnieniu tak licznych powiązań między różnymi elementami życia gospodarczego i społecznego zagrożenia można postrzegać w skali makro i mikro. Niejednokrotnie mogą to być tzw. bomby z opóźnionym zapłonem o czym nie wiemy. To raz jeszcze akcentuje fakt, że prawdopodobieństwo zaistnienia sytuacji (zdarzeń) kryzysowych jest stosunkowo duże. Fakt ten implikuje potrzebę podejmowania stosownych działań.

Niestałość otoczenia wraz z ewentualnymi skutkami zaistnienia zagrożeń zwyczajnych czy nadzwyczajnych wprost zmusza do nieustannej konfrontacji teraźniejszości z przyszłością. Trzeba monitorować, analizować, dokonywać uogólnień i formułować wnioski jako swego rodzaju sugestie działań na zaistnienie zdarzeń niekorzystnych dla społeczeństwa i (lub) środowiska. Przy czym te szczególnego rodzaju wyzwania należy traktować jako bardzo istotne bo zawsze, bezpośrednio lub pośrednio, dotyczą pojedynczych osób, jak i zbiorowości.

Okoliczności zdarzeń kryzysowych rzutują na wiele kwestii. W kontekście poruszanych zagadnień wyraźnie akcentują oczekiwania wobec ratowników. Przede wszystkim należy pamiętać o tym, że w każdej organizacji, a organizacji publicznej w szczególności, personel należy traktować podmiotowo. Ludzie muszą mieć świadomość swej roli, własnego udziału w procesie zarządzania kryzysowego. Chcą mieć zadowolenie z tego co robią. W całej rozciągłości odnosi się to do ratowników, dla których satysfakcja $\mathrm{z}$ realizacji zadań, często nawet $\mathrm{z}$ narażeniem własnego życia czy zdrowia, ma znaczenie istotne. $\mathrm{W}$ tym jednak przypadku owe uczucie przyjemności nie musi mieć wymiaru formalnego. Dla ratowników największą radością i zarazem satysfakcją jest pomyślne wykonanie zadania bez uszczerbku dla innych i środowiska.

Ponadto na uwadze trzeba mieć jeszcze jedną kwestię. Likwidacja skutków czy konsekwencji wspomnianych zagrożeń to przede wszystkim domena specjalistycznych organizacji publicznych. Zżzycia wynika, że niejednokrotnie uczestniczą w tym osoby postronne nie zawsze posiadające 
odpowiednie kwalifikacje. To zaś czasami sprawia, że ze spontanicznych ratowników stają się osobami potrzebującymi pomocy. Fakt ten akcentuje potrzebę edukacji społecznej.

Należy podkreślić, że ewentualnych zdarzeń (sytuacji) kryzysowych może być dużo. Różnić się mogą między sobą skalą, zasięgiem i czasem trwania zagrożenia dla ludzi (społeczeństwa) czy środowiska. Analiza wydarzeń, które miały miejsce w ostatnich latach pozwala wysnuć wniosek, że jakiekolwiek próby sprowadzenia zdarzeń kryzysowych do wspólnego mianownika z góry są skazane na niepowodzenie. Pomiędzy poszczególnymi sytuacjami występują dość istotne różnice we wszystkich czterech etapach zarządzania kryzysowego. Odmienna jest procedura postępowania (działalność) organów administracji publicznej będąca elementem kierowania bezpieczeństwem narodowym, która w tego rodzaju zdarzeniach polega na zapobieganiu sytuacjom kryzysowym, przygotowaniu do przejmowania nad nimi kontroli w drodze zaplanowanych działań, reagowaniu w przypadku wystąpienia sytuacji kryzysowych, usuwaniu ich skutków oraz odtwarzaniu zasobów i infrastruktury krytycznej.

Każda sytuacja kryzysowa jest niepowtarzalna. Fakt ten w przełożeniu na język działania praktycznego oznacza, że do wszelkich zdarzeń trzeba podchodzić indywidualnie, a podczas zarządzania kryzysowego należy być elastycznym. Taka teza nie wyklucza analizowania tego co miało miejsce. Trzeba to czynić, ale z pewną dozą ostrożności. Raz sprawdzonych procedur czy rozwiązań nie można bezkrytycznie kopiować lub przenosić w inne miejsce. Należy pamiętać o tym, że w każdej sytuacji mamy do czynienia z innymi ludźmi, zarówno ratownikami, jak i osobami oczekującymi pomocy lub wsparcia ze strony organów administracji publicznych.

Z teorii organizacji i zarządzania jasno wynika, że podstawą każdego racjonalnego działania jest posiadany przez podejmującego zmagania pogląd, wyobrażenie lub koncepcja oraz pomysł; zamiar i chęć czy też obowiązek zrobienia czegoś, co powinien i co może zrobić (co wynika z jego roli, powinności i uprawnień). Myślenie powinno być naturalnie kreatywne, twórcze, pozytywne, tzn. że podejmujący działania powinien mieć wiarę we własne możliwości działania i wiedzę oraz chęć rozwiązywania problemu, który tego wymaga i powinien też mieć zdolność patrzenia na problem $\mathrm{z}$ różnych punktów widzenia. Powinien wszystko gruntownie przemyśleć (naturalnie, jeśli czas na to pozwala), ustalić fakty i je przeanalizować oraz logicznie połączyć ze sobą, stworzyć sobie pewną koncepcję, rozważyć różne możliwości i znaleźć jakiś zadawalający go wariant rozwiązania, które stanowiłoby inspirację do sformułowania strategii [13]. Innej alternatywy nie ma. Wiele problemów w organizacjach publicznych wymaga myślenia do przodu, myślenia perspektywicznego, strategicznego, dostrzegania i wykorzystania nowych możliwości, działania z wyobraźnią i elastycznością. Taka filozofia (i strategia zarazem) jest nieodzowna zwłaszcza w sytuacjach złożonych, gdzie zdrowie i życie ludzkie jest w niebezpieczeństwie. Dla wszystkich osób realizujących konkretne zadania w sytuacji (zdarzeniu) kryzysowym powinno to być zrozumiałe. Taka optyka postrzegania zjawisk wynika $z$ faktu, że w centrum każdego rozumowania są zawsze ludzie, że efektywność działania musi też respektować szacunek dla wartości ludzkich, a więc traktowanie ich nie w sposób instrumentalny, jako narzędzie do realizacji celów lecz poważne partnerskie traktowanie, uznanie ich interesów za pełnoprawne, a ich pragnień za żywotne.

Instytucje publiczne, predysponowane do aktywnego udziału w różnego rodzaju zdarzeniach losowych, funkcjonują w ściśle określonym środowisku i niezależnie od swej wielkości, terytorialnego rozmieszczenia, specyfiki działania, spełniają określoną rolę w systemie zarządzania kryzysowego. Jest tam personel, który nie tylko uczestniczy w osiąganiu nakreślonych celów i (lub) w spełnianiu określonej funkcji. Dla zatrudnionych istotne jest także to, że dzięki swej aktywności zawodowej może rozwijać się i podejmować nowe wyzwania. Ich realizacja pozostaje w ścisłym związku z kulturą i zachowaniami organizacyjnymi. Koresponduje to $\mathrm{z}$ nowymi wyzwaniami jakie niesie z sobą coraz bardziej burzliwa współczesność. Dla firm i instytucji oznacza to, że trzeba być zdolnym do modyfikacji swego postępowania i racjonalnej reakcji na zmienność otoczenia.

Każda społeczność jest zróżnicowana. W odniesieniu do ratowników, niezależnie jak ich będziemy określać, nie można zapominać o zróżnicowaniu poszczególnych zespołów. Nie wynika ono jedynie z faktu, że są predysponowani do realizacji innych zadań i dysponują wysoko specjalistycznym sprzętem. Poszczególni przedstawiciele instytucji publicznych różnią się między sobą nie tylko pod względem cech osobowych. Spośród mnogości występujących odmienności za zasadne jest wspomnieć jeszcze o tym, że mają różną wiedzę, umiejętności, stosunek do pracy (służby). Ponadto nie wszyscy kierowali się tymi samymi przesłankami, podejmując pracę zawodową w instytucjach publicznych, których głównym przesłaniem jest nieść pomoc innym i przeciwdziałać zjawiskom niekorzystnym dla ludzi i środowiska.

\section{Podsumowanie}

Przybliżenie tych kwestii autor uznał za stosowne, bowiem kierujący (dowodzący) musi znać swoich podwładnych i wiedzieć jakie są ich predyspozycje i możliwości; jak najprawdopodobniej zachowają się w sytuacji zagrożenia swego zdrowia i życia. Znajomość tych ocen nieodzowna jest nie tylko przy doborze ludzi (ratowników) do zespołów. To także istotna informacja, głównie pod kątem kogo i jak szkolić, jakie i w jaki sposób podnosić (doskonalić) kompetencje całych grup, jak i pojedynczych osób. Nie mniej istotne jest, aby wysokiej klasy specjalistów utrzymać w danej instytucji publicznej. A jak wiadomo nie zawsze jest to możliwe $\mathrm{z}$ uwagi na rosnące zapotrzebowanie na pracowników - specjalistów.

„Znaczne grono teoretyków, a przede wszystkim praktyków przypomina, że organizacje publiczne są zbiorem elementów, dzięki którym grupy ludzi utrzymują stosunki w procesie świadomego i systematycznego ustalania i wykonywania wzajemnie akceptowanych celów" [12]. Akcentują, że aby cele te były możliwe do osiągnięcia, nieodzowne jest, 
aby wszyscy członkowie organizacji byli elastyczni i dostrzegali ciągłą potrzebę doskonalenia swych kompetencji, byli kreatywni i cechowali się duchową pomysłowością [14]. To także szczególny wymóg wynikający z konieczności ciągłego dostosowywania się do przemian w otoczeniu i dostrzegania zmian wśród personelu. Nieodzowne jest podejmowanie działań zmierzających nie tylko do wykształcenia kompetentnego personelu, ale także do tego, aby czuli oni satysfakcję z tego co robią i gdzie to czynią oraz identyfikowali się z firmą (instytucją). W ślad za tym przełożeni muszą nie tylko reagować na zakłócenia w środowisku funkcjonowania, ale muszą także ponosić odpowiedzialność za podejmowane działania - muszą zdawać sobie sprawę $\mathrm{z}$ różnorodnych skutków dokonywanych rozstrzygnięć. Kadra kierownicza (dowódcza) musi podejmować szereg decyzji, działając w złożoności różnorodnych problemów i z poszanowaniem różnorodności. Istotne jest przy tym, aby to wszystko odbywało się na wysokim poziomie kultury poszczególnych osób, jak i kultury całej organizacji publicznej. Obecnie inaczej być nie może. Wysoki poziom kultury wraz z etyką musi być trwałym elementem każdej organizacji uczestniczącej w zarządzaniu kryzysowym, ponieważ tylko zróżnicowany zestaw wartości, norm zachowań będzie wpływał na postawy i zachowania personelu, a przez to na efektywność konkretnej organizacji publicznej. Z drugiej zaś strony, jej kultura wpływa korzystnie na relację z środowiskiem, przez co tworzy się korzystny obraz danej instytucji publicznej i jej postrzeganie przez interesariuszy i społeczeństwo, co ma szczególny wymiar w odniesieniu do społeczności lokalnych.

Niemałe oczekiwania pod adresem personelu instytucji angażowanych do realizacji zadań w różnych fazach zarządzania kryzysowego nie jest przypadkowe. Przecież to od ludzi, ich postaw, zaangażowania, odporności zależy nie tylko umiejętność wykorzystania posiadanych sił i środków. Oprócz tego osoby uczestniczące w likwidacji skutków zaistniałych sytuacji kryzysowych są podatni na stres, podlegają tym samym zjawiskom jak każdy inny człowiek w sytuacji zagrożenia życia. Ponadto ratownicy działają na własnym terenie i niejednokrotnie niosą pomoc ludziom, wśród których mogą być również najbliżsi. Wtedy też mogą się pojawić wątpliwości, a w konsekwencji zmieniona gradacja zadań.

\section{Literatura}

[1] Kitler W., System zarzadzania kryzysowego w dziedzinie bezpieczeństwa narodowego RP, [w:] Bezpieczeństwo narodowe i zarzadzanie kryzysowe $w$ Polsce $w$ XXI wie$k u$ - wyzwania i dylematy, T. Jemioło, K. Rajchel (red.), Warszawa 2008, s. 393.

[2] Sobolewski G., Zagrożenia kryzysowe, Akademia Obrony Narodowej, Warszawa 2011, s. 15.

[3] Ścibiorek Z., Ludzie - cenny kapitał organizacji, wyd. Adam Marszałek, Toruń 2004.

[4] Ścibiorek Z., Oddziaływanie na personel służb mundurowych, PTM, Warszawa 2014.

[5] Urban A., Bezpieczeństwo społeczności lokalnych, Warszawa 2009 .
Trzeba pamiętać także o tym, że nie istnieje jeden, uniwersalny styl zarządzania (dowodzenia) sprawdzający się we wszystkich instytucjach publicznych i podczas każdej sytuacji kryzysowej. Aby odnosić sukcesy, trzeba umieć funkcjonować w wielokulturowych i zróżnicowanych środowiskach. Tylko bowiem połączenie różnych pierwiastków kulturowych i osobowościowych pozytywnie wpłynie na uzyskanie efektu synergii. Niebagatelne znaczenie ma kreatywność oraz zdolności dyplomatyczne i umiejętność prowadzenia negocjacji, a także umiejętność działania w sygnalizowanej różnorodności. Posiadany przez przełożonych kapitał intelektualny będzie istotną przesłanką do dużej efektywności działań w różnych miejscach i sytuacjach oraz profilach działalności organizacji. Zadania będą realizowane na wysokim poziomie i z korzyścią dla nas wszystkich.

Potrzeba ustawicznego dostosowywania się personelu i organizacji publicznych do zmieniającego się otoczenia, czasami wręcz rewolucyjnego, nie jest zjawiskiem korzystnym dla trwałości przyjmowanych rozwiązań. Warunki sprawiają, że zmieniają się dotychczasowe zasady gry. Zmieniający się świat tworzy zapotrzebowanie na nowe instytucje, na zmianę wymiaru i zakresu działania tych istniejących, którym przychodzi funkcjonować w warunkach coraz mocniejszej współpracy między sobą oraz z nowymi partnerami. Wygenerowane zaś pomysły dość szybko stają się kategorią historyczną.

W konkluzji rozważań można sformułować postulat pod adresem osób i instytucji naukowo-badawczych i ośrodków akademickich. W wyniku wszechstronnych i kompleksowych badań powinna być stworzona teoria umożliwiająca pełne wykorzystanie potencjalnych możliwości, zarówno ludzi, jak i pozostałych zasobów będących w gestii osoby (osób) kierującej przebiegiem akcji, niosącej w pierwszej kolejności pomoc poszkodowanym i ograniczającej skalę wtórnych strat i zniszczeń, a w następnej kolejności usuwającej skutki zaistniałej sytuacji kryzysowej. Teoria ta w istotny sposób wpływać będzie na sposób, zakres i intensywność działań, stworzy także możliwość alternatywnego działania, które dzięki użyciu posiadanych zasobów w istotny sposób wpłynie na efektywność podejmowanych akcji, a skala niekorzystnych konsekwencji dla ludzi i środowiska zostanie ograniczona.

[6] Kuc R.B., Ścibiorek Z., Podstawy metodologiczne nauk o bezpieczeństwie, Wydawnictwo Menedżerskie PTM, Warszawa 2013, s. 6.

[7] Pokruszyński W., Teoretyczne aspekty bezpieczeństwa, Wyższa Szkoła Gospodarki im. Alcide De Gasperi w Józefowie, Józefów 2010.

[8] Determinanty bezp. międzynarodowego (polityczne, ekonomiczne i gospodarcze, cywilizacyjne, militarne), [dok. elektr.], http://cojawiem.pl/pl/articles/ 14693-determinanty-bezp-miedzynarodowego-polityczne-ekonomiczne-i-gospodarcze-cywilizacyjne-militarne, [dostęp: 26.06.2014]. 
[9] Scholte J.A., Globalizscja, Humanitas, Sosnowiec 2006, s. 31.

[10] Klimek J., Etyka biznesu w warunkach silnej konkurencji, [dok. elektr.], http://www.ue.katowice.pl/uploads/ media/9_J.Klimek_Etyka_biznesu_w_warunkach_silnej.... pdf [dostęp: 22.06.2014]

[11] Ścibiorek Z., Motywowanie w organizacjach publicznych, WSPol, Szczytno 2014, s. 27-28.
[12] Kuc R.B., Zarządzanie doskonałe, Wydawnictwo Menedżerskie PTM, Warszawa 2008, s. 121-122.

[13] Kuc R.B., Od zarządzania do przywództwa, PTM, Warszawa 2004, s. 146-150.

[14] Klimek J., Społeczna odpowiedzialność biznesu w Polsce, Toruń 2012, s. 121.

płk rez. prof. dr hab. inż. Zbigniew Ścibiorek - były długoletni pracownik Akademii Obrony Narodowej. Prodziekan Wydziału Zarządzania i Dowodzenia tej uczelni. Były kierownik Katedry Systemów Zarządzania Akademii Podlaskiej w Siedlcach, dawny pracownik ORGMASZ-u i Uniwersytetu Jana Kochanowskiego w Kielcach. Obecnie profesor zwyczajny Wyższej Szkoły Oficerskiej Wojsk Lądowych we Wrocławiu. Zasadnicze obszary zainteresowań dotyczą: zarządzania kryzysowego, problematyki podejmowania decyzji kierowniczych (dowódczych), przeprowadzania zmian w organizacji. 